\title{
The Autonomy of Digital Native Generation in Building Nation Branding (Case Study: YouTuber Alip_Ba_ta)
}

\author{
Agung Eko Budiwaspada ${ }^{1}$ Fadilah Fadilah ${ }^{2, *}$
}

\author{
${ }^{1}$ Institut Teknologi Bandung, Indonesia \\ ${ }^{2}$ Institut Teknologi Bandung, Indonesia \\ *Corresponding author: fadillah@itb.ac.id
}

\begin{abstract}
The milestone of technological evolution has reached the level of 4.0. Persuasive messages in the media have also evolved in a disruptive direction. Social media has degraded the existence of asymmetrical mass media, where producers as elite role tend to dictate the society as target audience. The synergy between digital technology and the digital native generation, with their creative and confidence character, is driving the performance of social media and create equal roles between the producers and target audience. This phenomenon is giving equal power, where individuals owned their greater independence, both as messages sender and recipient. One example is the power possessed by the digital native generation in delivering nation branding through social media in the eyes of global citizen. This nation branding usually created by the government as an elite party. On the other hand, globalization, which was originally oriented to create universality as a form of big narrative, has in fact emerged resistance from small local narratives facilitated by social media. The gap that arises due to difference between theory-driven and practical-driven about branding concept is an important issue to be discussed. Using social semiotics, Youtube channels created by Indonesia's digital native, Alip-Bata will be analyzed to describe their autonomy process in creating creative content on social media. The $4 \mathrm{E}$ variable of digital marketing mix was used in order to map the gap between traditional and the newest branding concept. This mapping process creates a redefinition of nation branding concept, in which citizens are autonomously given a new concept to reduce the dominant role of the main stakeholder whom usually formulates and creates the concept. The redefinition potentially creates gaps and counterproductive in achieving nation branding awareness. In order to minimize the gap between theory and practice, the traditional and new concepts need to be synergized.
\end{abstract}

Keywords: Nation Branding, Digital Native Generation, Social Media

\section{INTRODUCTION}

Academic has unique norms, value systems, resources, ways of communicating, stakeholders, governance systems and accompanied by various rituals that present its own atmosphere. This kind of culture can be embodied in the rules and regulations, behavior patterns and the material facilities. It mainly consists of academic spirits and academic ethics [1]. The academic space, with its exclusivity, is completely different from other. Academic space is deemed necessary to be sterile from certain interests, because it is a free zone for all learners. Not only sterile and exclusive, academic also contain the hierarchy of caste, which the higher the caste, the higher the appreciation. As the holder of a sacred scientific authority, to enter academic space, certain requirements are needed. Professionals from various fields of expertise are trying to enter this honourable place, a place with rigid nomenclature of study programs system. In such rigidity, branding has had a private authority which commonly associated with science of image. The dynamics of branding always coexists with the world of culture, social, politics, economics, and technology, which significantly influences imaging activities. As explained in theory about building an image, attraction is needed to summon as many people as possible who are 
considered as potential audiences. Competition occurs when certain audiences are contested by parties who have the same interests. To win this competition, the branding process must be intelligently conceptualized by using the art of persuasion.

In the context of nation branding, the emerging phenomenon is that every country seems to improve, manage, adapt, and to restore its international reputation through a branding program. To achieve this goal, many of them are trapped in the misconception about branding. In parity, these countries promote images of beauty, luxury, progress, prosperity, and various other symbolic narratives, which in fact build lead to distortions about nation branding. The state is considered as a company that produces solely services product. In fact, nation branding is more complex, because its wider and comprehensive point of view in reflecting the country's reputation. Basically nation branding narrates about various products from culture, tourism, investment, technology, education, business, people, policies, initiatives, and various events. Those persuasive narratives ultimately create an image of the nation, and become a major intangible asset. Improving the nation's image in the international arena is absolutely concentrated on developing a reputation, rather than building beautiful images. A nation is judged by what it has done, not by what is said or broadcast, and to that, there are no shortcuts.

In building a reputation, globalization seems to produce a great universal narrative. But in practice, what happens is the other way around. Globalization actually produces small and diverse narratives about the local values that appear as the dominant discourse in building nation branding. In order to emphasize this view, the formation of branding image also occurs in commercial advertising as well. The globalization era has created a great narrative about the stereotypes of creative advertising ideas which in turn create sub-narratives about locality. This is in line with the postmodern discourse that positioned pluralism as one of its main ideas, in a way that encourages local phenomena as well as criticism of universality in the construction of the global culture [2]. Globalization is not an inclusive or progressive form of internationalism. Rather, it is the successful expansion on a world scale of particular localisms of social, economic, and political organization [3]. Universality has become a stereotype of nation branding as a theoretical reference for the government, which in practice uses branding consultant services with an academic concept approach [4]. The circle of the production process for the big narrative of nation branding is different from the pattern of producing various small narratives about locality.

Nowadays, small narrative diversity is produced by YouTubers - the digital native generation - who have creative, confidence and connect characteristics [5]. The technology milestone has reached level 4.0. In 4.0 era, media which is a tool for conveying nation branding has evolved from mass media to social media [6]. The use of social media greatly influences how a nation is represented to a global audience [7]. This media shift significantly changes the way the audience thinks, behaves and acts in responding to and interacting with a nation brand. The birth of social media disrupts mass media entities that have tended to dictate to society. On the other hand, social media facilitates the birth of an equal role between the message owner and the audience. The equality law has encouraged greater independence for individuals to play a role in the nation branding ecosystem. The existence of great narrative versus diversity of small narative stereotypes suspected creating a gap between theory-driven and practicaldriven about branding concept. it is necessary to give the new recommendations on how to reduce this gap. This is very important considering that culture has a very important role in developing a nation. The economic, political, and social dimensions can be global as far as all three have been civilized [8].

\section{METHODS}

Using interpretative phenomenological analysis, this research trying to explore and investigate the gap between theory-driven and practical-driven about nation branding concept. Using with social semiotics theory [9] and 4E's of Marketing theory [10], this research tried to focus on idiographic that it aims to offer insights into how a given context could makes sense of a given phenomenon. YOUTUBE was chosen because it has the breadth of reach and the explosive impact power in creating nation brand awareness. Youtuber finger style guitar Alip Ba_Ta was chosen purposively (criterion based) as the subject of the study because it is viral worldwide and can be considered as a representation of the digital native generation, associated by the audience as a representation of Indonesia. Youtuber Alip_Ba_Ta's uploaded content which is used as a source of semiotics, then observed as a media text discourse, which includes the field of discourse, tenor of discourse, and mode of discourse to generate engagement. 
The field of discourse discussion is carried out to find which object is the discourse, based on the response and how the YouTube channel Alip_Ba_ta is treated as an object of news. For discourse participants, the discussion is focused on knowing the nature, position, and role of the people who appearon the Alip_Ba_ta YouTube channel as text. The discussion of discourse facilities is oriented to find the role of Alip_Ba_Ta in describing the terrain and involvement that implies meaning, images, opinions and motives that lead to Indonesia's nation branding. These three fields are explored qualitatively through text analysis concerning the reciprocal relationship between media content and its audience as the engagement of Alip_Ba_ta's YouTube channel.

Furthermore, the results of the engagement are constructed using the 4E's of marketing variables (Experience, Exchange, Everyplace, and Evangelism). The Experience variable is discussed in the way Alip_Ba_Ta provides an opportunity for the audience to relate emotionally to the content presented. The Exchange variable is not about how many values are set by Alip_Ba_Ta, but what the audience will be if they consume Alip_Ba_Ta's uploads. Everywhere variable addresses the ability to capture and encourage the desire to consume Alip_Ba_Ta's uploaded content wherever the audience is. Everywhere variable highlights the performance of Alip_Ba_Ta's upload which uses his audience as an agent to bring good news about him. The results of this construction are synthesized as a manifestation of the autonomous role of digital native generation in nation branding formation. This role is ultimately used as the basis of recommendations in an effort to reduce the gap between the academic, as it has been used by the government, and the practice of nation branding which is automatically played by the digital native generation.

\section{RESULT AND DISCUSSION}

Departing from the use of YouTube platform by digital native generation and nation branding as the main concern, thus understanding the migration of media from "one to many media" to "many to many media", the evolution of the marketing mix from 4Ps to $4 \mathrm{Es}$, is the main basis discussion in this critical study. These theories ideally need to be comprehensively described and framed the discussions. However, it should be realized that an in-depth description is not possible on this timelimited critical study. Therefore, in this, these theories are only reviewed from the most important and relevant aspects.

\subsection{Engagement Alip_Ba_ta YouTube Channel in the perspective of Social Semiotics}

As reported by Forbes in June 2021, YouTube Remains the Most Dominant Social Media Platform. Founded in 2005 by former PayPal employees Chad Hurley, Steve Chen, and Jawed Karim, YouTube is a digital platform where all users share videos [11]. Based on the latest statistics, the video-sharing platform has 2.3 billion users worldwide as of 2021 [12]. Considering that people is allowed to view all the videos without having to register through a Google account (such as via the auto play feature in WhatsApp), YouTube's reach ability is increasing. Not only as a social network platform, Youtube provides the most used search engine service after Google. This means, users get two services that exist on the two largest platforms, namely Facebook and Google. YouTube is not only accessible but also strives to localize its services in more than 100 countries. The platform adapts to different languages of different markets and can be accessed in 80 different languages.

The reasons people enjoy watching and following YouTubers can be summed up in three words: fun, authenticity and learning. They like YouTube video content because it has entertainment value, naturally presented as it is and provides relevant information, including how to win video games [13]. With the tagline Broadcast Yourself, YouTube provides space for anyone to contribute content [14]. In 2011, the concept of Broadcast Yourself changed, not only in reference to the platform's capacity to distribute selfmade personal content globally but also the ability to redistribute professional content that already broadcast on television [15]. Since this change, there have been people who create content personally but try to compete in producing quality content that is competitive with professional content. They are then called Youtubers. In assessing the content created by Youtubers, users can choose desired content according to their preferences.

YouTube, as an integral part of social media, places content creators and content recipients in a symmetrical position with intense interaction. The intensity of this relationship can be stated that the viewer not merely as a passive subscriber, but has a great chance to comment, make recommendations, even collaborate by modifying the content. In the context of network society, social media messaging 
becomes decentralized, i.e. power and control are interwoven more broadly. Distribution of power and control of individual media content becomes autonomous [16]. The presence of social media, especially YouTube, has become a comfortable place to accommodate expressive and creative content of the digital native generation.

In accordance with the method that has been presented, the discussion of the discourse field is carried out to find out what is the discourse based on the response and how the YouTube channel Alip_Ba_ta is treated as an object of news. In the discourse section, the discussion is focused on knowing the nature, position, and role of the people who appear on the Alip_Ba_ta YouTube channel as text. The discussion of discourse facilities is oriented to find out the role of Alip_Ba_Ta in describing the terrain and involvement that implies meaning, images, opinions and motives that lead to the Indonesia's nation branding. These three fields are explored qualitatively through text analysis concerning the reciprocal relationship between media content and its audience as the engagement of Alip_Ba_ta's YouTube channel.

Field of Discourse. In observing YouTube media text discourse, it was found that the terminology of fingerstyle guitar, video reaction, video collaboration, and video influencer became a field of discourse variable in semiotics. The Fingerstyle comes from the phrase fingerpicking-style, which is literally defined as a guitar strumming technique in which the strings are plucked directly by the fingertips, nails, and other parts of the finger. But more than that, fingerstyle is a complete package of various guitar and strumming techniques. Fingerstyle guitar is a musical improvisation technique both on instruments and song, which is considered as the center of a radical innovation in musical instrumentation [17]. In the fingerstyle community, the quality of Alip_Ba_Ta's guitar playing has been recognized by a worldwide audience. His humble appearance and without even asking his audience to call for action, has become one of Alip_Ba_Ta's charms. The content of using fingerstyle guitar as cover of famous songs is able to inspire audiences both locally and globally, even fellow YouTubers give positive reactions and are moved to create collaborative content.

Reaction video is a form of reaction signal to a particular fact or phenomenon. In this discourse, a reaction video was created to express the Youtube audien's emotional reaction to the Alip_Ba_Ta's fingerstyle material as an object of social media content. The emotional reaction was given because of Alip_Ba_Ta's reputation in terms of competence in playing fingerstyle guitar, which was carried out by musicians or music experts. Furthermore, the emotional reaction to Alip_Ba_Ta's style in terms of his humble appearance and his ability to choose songs to compose, was given by common people who are generally unfamiliar with fingerstyle guitar technique. Both of these acknowledge that every content uploaded by Alip_Ba_Ta has a high standard

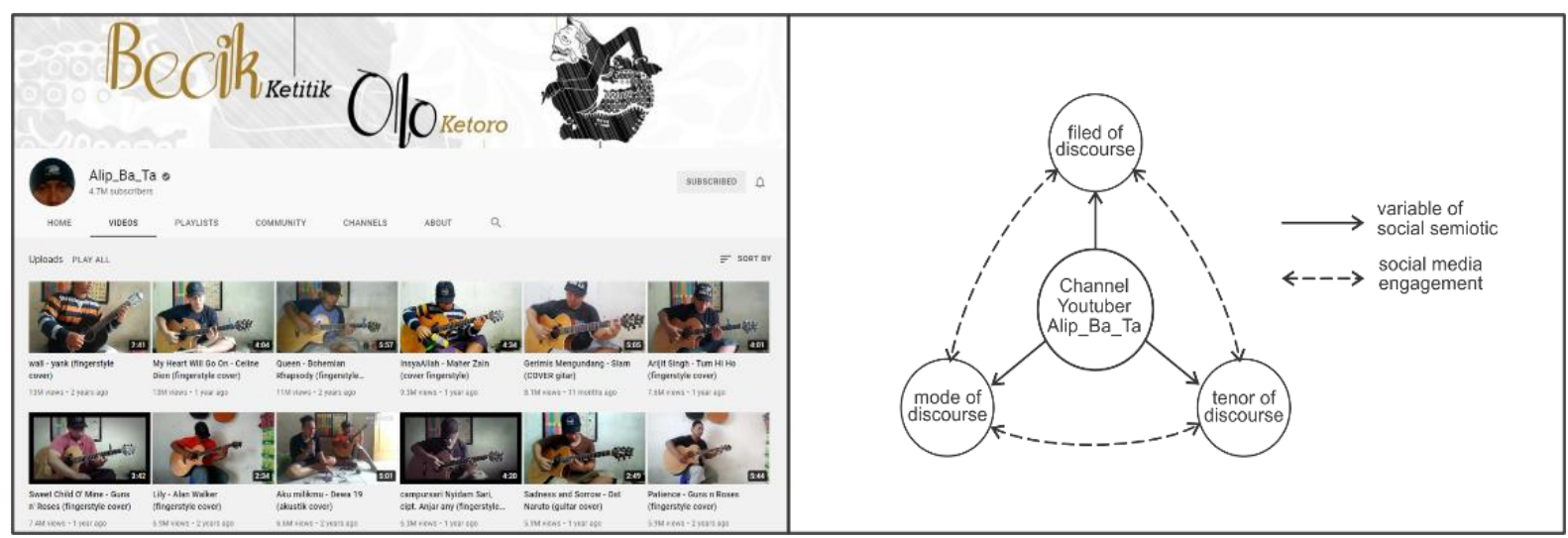

Figure 1. (a) YouTube channel Alp_Ba_Ta. (accessed July 7th 2021, 8:12 PM); (b) YouTube channel engagement. 
in the technical quality of fingerstyle guitar playing and has a consistent value of modesty. This recognition is Alip_Ba_Ta's personal image that makes him unique and different from others. There are 3 (three) main dimensions forming personal branding, namely individual competence or ability, personal style or style, and personal standards of a person [18].

Collaborative videos between content creators are carried out to increase one's channel awareness. Creating collaborative videos is intended to attract the attention of the audience from both the channels. This orientation will work as long as the viewers and the content between the two have relevance. In addition to attracting new viewers, collaborative videos can also develop social networks between channel owners. The wider the social connections a channel has, the more likely it is for these channels to collaborate, especially with channels that already have a high subscriber count. The Alip_Ba_Ta channel has become a high field of collaboration video discourse. Collaboration is done by singing

Table 1. Channel YouTube Alip_Ba_ta Engagement and/or adding parts of other musical instruments to the content that has been uploaded by Alip_Ba_Ta. Influencers who have a large number of subscribers are seen as a strategy to increase one's YouTube channel engagement. In general, influencers are selected based on their abilities, expertise, level of popularity, and reputation. The selection of influencers is carried out by considering the alignment of the positioning concept, the target audience and the level of platform involvement. This is also expected to create a community that supports the existence of one's YouTube channel. The Alip_Ba_Ta channel actually creates a deviation from the nature of the use of influencers as described. YouTubers who like fingerstyle guitar playing AlipBa_Ta joined to form a community called Alipers. Furthermore, in this field of discourse, the Alipers became Alip_Ba_Ta influencers at national and international levels. Reaction videos, collaboration videos, and influencer videos are effective ways to reach wider new audiences, in the law of symmetrical equity concept of social media. Social

\begin{tabular}{|c|c|c|}
\hline Category & Discourse Finding & Discourse Narrative \\
\hline $\begin{array}{l}\text { Field of } \\
\text { Discourse }\end{array}$ & $\begin{array}{l}\text { - Fingerstyle guitar } \\
\text { - Video reaction } \\
\text { - Collaboration } \\
\text { - Influencer }\end{array}$ & $\begin{array}{l}\text { Alip_Ba_Ta fingerstyle guitar game has become a YouTube } \\
\text { content phenomenon, not only refers to capacity of globally } \\
\text { distributing their personal content, but also the ability of } \\
\text { redistributing the content on other personal platforms in the form } \\
\text { of video reaction, video collaboration, and other contents to } \\
\text { influence the existence of Alip_Ba_Ta. The treatment of } \\
\text { Alip_Ba_Ta channel has legitimized the social media } \\
\text { characteristic in producing a symetrical relationship between the } \\
\text { sender and the recipient of the message, degrading the } \\
\text { asymmetrical characteristics of mass media in the distribution of } \\
\text { information. }\end{array}$ \\
\hline $\begin{array}{l}\text { Tenor of } \\
\text { Discourse }\end{array}$ & $\begin{array}{l}\text { - Alief Gustakhiyat } \\
\text { - Viewers } \\
\text { - Subscribers } \\
\text { - Alipers }\end{array}$ & $\begin{array}{l}\text { Everyone listed in the social media captions are parties involved in } \\
\text { the engagement of the Alip_Ba_Ta YouTube channel. They } \\
\text { contributed greatly in making Alief Gustakhiyat's Alip_Ba_Ta } \\
\text { YouTube channel globally viral according to their perspective } \\
\text { roles as YouTubers (source of semiotics), viewers (audience), } \\
\text { subscribers (customers), and Alipers (influencers). }\end{array}$ \\
\hline $\begin{array}{l}\text { Made of } \\
\text { Discourse }\end{array}$ & $\begin{array}{l}\text { - YouTuber creative } \\
\text { strategy } \\
\text { - From zero to hero } \\
\text { - From personal to } \\
\text { nation branding }\end{array}$ & $\begin{array}{l}\text { Numerous type of YouTube content drives YouTubers to steal } \\
\text { audiances' attention who are generally looking for fun, such as } \\
\text { authenticity and learning material content. Alip_Ba_Ta is one of } \\
\text { many YouTubers who has successfully applied this creative } \\
\text { strategy. Alief Gustakhiyat's reputation in the global arena ensures } \\
\text { that the synergy of social media performance and the digital native } \\
\text { generation that is managed using the right creative strategy can } \\
\text { ultimately create a narrative of "from zero to hero" and "from } \\
\text { personal to nation branding". }\end{array}$ \\
\hline
\end{tabular}


media engagement, which has become a field of discourse, has begun to disrupt the establishment of mass media, which tends to dictate society. This condition is a form of migration as well as bipolarization from the previous era, where the mass media created an asymmetrical attitude. In this era, the target audience has very few opportunities to share their perceptions with other recipients of the message. Meanwhile, the media freely presents content according to their business interests [19].

Tenor of Discourse. As a media text, Alip_Ba_Ta who was born in Ponorogo, East Java, Indonesia in 1988, is a fingerstyle guitar musician. Alip_Ba_Ta played as digital native who is creative, think outside the box, rich in ideas and able to actualize these ideas. The term of Digital Native was first proposed by Percy in order to discuss the identification of learner characters based on the emergence of technological influences [20]. Digital natives are learners who are "native speakers" of the digital languages of computers, video games, and the internet. They are a new generation with a very different and complex of cognitive skills from their predecessors [21]. Percy did say that digital natives are people born after 1990. But the issue of this term is not only related to what year this generation was present but that digital natives are the net generation that is always surrounded and uses computers, video games, digital music players, cell phones and other digital toys, much of which occurred after the 1980s [22]. They are connected individuals who are good at socializing, especially in their communities, actively surfing social media and the internet, not only based on the quantity of time but also the depth of the surfing process. Digital native are people with confidence, they dare to express opinions and don't hesitate to debate in public areas regarding various things through social media [23]. Alip_Ba_Ta is considered modest, very confident, dares to express his existence in the public area through social media [24]. He do not always provide certain material for their followers to study, but appear as figures who use the same language style, similar sense of humor, entertain followers with content that taken without using a particular transcript so that it feels natural. They have the same view against conventional irrelevant social values [25].

As one of the representations of the digital native generation, Alip_Ba_Ta received positive reactions from millions of viewers and subscribers - discourse participant - both from common people and famous musicians, local citizen and abroad. Richard Bienstock on the Guitar World website created an article entitled "This Indonesian YouTuber's acoustic fingerstyle cover of Guns N' Roses' Sweet Child O' Mine is Driving Guitarists Wild", stating that "As demonstrated on his Sweet Child cover, his flawless technique and extraordinary arranging skills, molding the song's lead and rhythm guitars, bass line, vocal and, in some spots, percussion, into one smooth and flowing (not to mention incredibly musical sounding) six-string part, is nothing short of astounding. In fact, he's already inspired a wave of reaction videos from other amazed YouTubers“ [26]. Social media opens a wide space for discourse participants to comment, provide recommendations, and even upload reaction video content, creating collaborative content containing modified videos from Alip_Ba_Ta. Those involved in the discourse of social semiotics relate intensely and loyally. This intensity and loyalty can be seen by looking at channel analytics which includes overview (viewers, subscribers), reach (impressions, unique viewers), engagement (watch time in hour, average view duration), audience (returning viewers, new viewers). This analytics then represented Alip_Ba_Ta as Indonesian top with a global reputation.

Mode of Discourse. Alip_Ba_Ta became a means of discourse which was interpreted as a phenomenal fingerstyle guitar by the viewers and subscribers. Those involved in the discourse gave positive opinions, especially regarding the fingerstyle guitar playing Alip_Ba_Ta which featured the technicalities of artificial harmonics, hammer on, pull off, legato, staccato, bending, tempo, tuning, and arrangement. The creative strategy adopted by Alip_Ba_Ta in playing these fingerstyle guitar techniques has earned him a lot of admiration, and many have called him a master, professor, and even the god of fingerstyle guitar. In a short time (first uploading content on YouTube on January 27, 2018), his channel now has 4.7 million subscribers, and each of his video uploads is seen by millions of people (see figure 1.a). Alip_Ba_Ta's YouTube channel became a field of discourse that was discussed as an object about the quality, creativity, and modesty of fingerstyle guitar players by discourse participants spread across various countries.

In the midst of various YouTube media contents, Alip_Ba_Ta's reputation is able to attract the world's attention. The figure of Alip_Ba_Ta as an individual who is framed by a personal image is gradually linked to his nationality, which inevitably contributes to increasing awareness of Indonesian, as a nation. 


\subsection{Role of Alip_Ba_Ta in Nation Brand from Digital Marketing Perspective}

Alip_Ba_Ta's role in building Indonesia's Nation Branding is inseparable from the shift of modern marketing mix to digital marketing mix. In order to emphasize this contribution, it is explained by comparing this two marketing concept in a way to capture Indonesia as an image. Nation branding is a systematic process to align the actions, behavior, investment, innovation, and communication of a country to create a clear strategy to achieve a strong identity to compete [27]. Nation branding arises when countries focus on carrying out a series of management techniques related to their country's brand so that they are ready to compete effectively in the global arena [28]. This is different from the concept of "Country of Origin" and "place branding" which focus on promoting certain economic interests (exports, tourism or investment). Nation branding focuses on the image of the country as a whole on the international stage which includes cultural, economic and other dimensions ([29].

The need for a country to be perceived as good has always been a central element in the government's agenda. There are many reasons for a country to build a certain image in global public. One of which is for political relations between countries, where the formation of this image is considered a persuasive effort in order to show "soft power" in the midst of relations between countries. Meanwhile, public opinion from other countries also constantly competes in the same way in the international political process [30]. In such a battlefield, the politics of image presentation requires the participation of all components, not just the sole power of the government.

The focus of nation branding refers to image and reputation that is enjoyed by all people in the world. An image that grows in the minds of people outside the country, is influenced by stereotyped perceptions resulting from media publicity and people's personal experiences of the country. The imaging mechanism is the same as for commercial brands, but the scope is more comprehensive. The treatment of nation branding programs referring to academic concepts has been carried out for several periods, and during that time it creates a bias towards tourism promotion. Tourism promotion is generally handled professionally by advertising agencies acting as consultants. Tourism promotion usually handled professionally by advertising agencies acting as consultants. One of the most prominent is the campaign entitled Wonderful Indonesia. The tourism campaign program is carried out using an academic method that refers to a modern marketing mix that implements the 4P concept, namely tourist attractions as Products, tourist spending measured as Prices, tourism exhibitions and travel agents as Places, and media placement as a vehicle for Promotion programs.

In 2018, the Ministry of Tourism budgeted 3.4 trillion for the Wonderful Indonesia Program. Such tourism campaign programs are often misunderstood as a nation branding program. This campaign program can be accepted as nation branding as long as the contribution can be seen in increasing nation awareness and strengthens identity. This program has succeeded in increasing 15.8 million foreign tourist visits. In fact, the 2018 Ministry of Tourism Performance Accountability Report document shows that none of them have recorded successful indicators related to nation branding concept, but being dominated by indicators related to the practical economic sector [31]. An academic tradition always requires success indicator parameter as program evaluation. The Wonderful Indonesia campaign is said to have played an important role in the Ministry of Tourism's 2018 Performance Achievements, towards: increasing national income from the tourism sector; increasing in foreign tourists and foreign tourists visit; increasing the competitiveness of national tourism; increasing investment in tourism sector; increasing the growth of the national tourism industry; increasing the quality of the national tourism business; and increasing the quality of national tourism human resources. In this Performance Achievements Report, none of which is explicitly stated its contribution to improving the image of the nation, which is the main objective of nation branding activities.

In the dynamics of marketing, which includes the realm of nation branding campaigns, there has been a shift from the modern marketing era to digital marketing era. This shift is marked by a shift in Product to Experience variables; from Price to Exchange; from Place to Everyplace; from Promotion to Evangelism [32]. The global presentation of Alip_Ba_Ta is strengthens this shifting process. In contrast to what the government does, which focuses its marketing efforts on tourism, Alip_Ba_Ta offers experiences and focuses on interactions that are built with viewers from all over aspects. Alip_Ba_Ta no longer only sells the songs that are played, but offers an experience to enjoy songs in order to meet the needs of the audience. The diverse needs of the audience's experience are presented in generic and flexible. It gives the 
experience by consuming the creativity of fingerstyle. The longing for simplicity in the midst of hedonic presentations displayed on youtube channels in general. Alip_Ba_Ta's reputation has inevitably turned into a stimulus that can increase awareness of nation branding.

In modern marketing, prices are determined by has always been associated with the Indonesia, as a nation.

In modern branding, distribution channels are used as a means to reach the branding target market. The place variable's main concern is physically approaching the target market. Branding requires storefronts/outlets or mass media channels as a

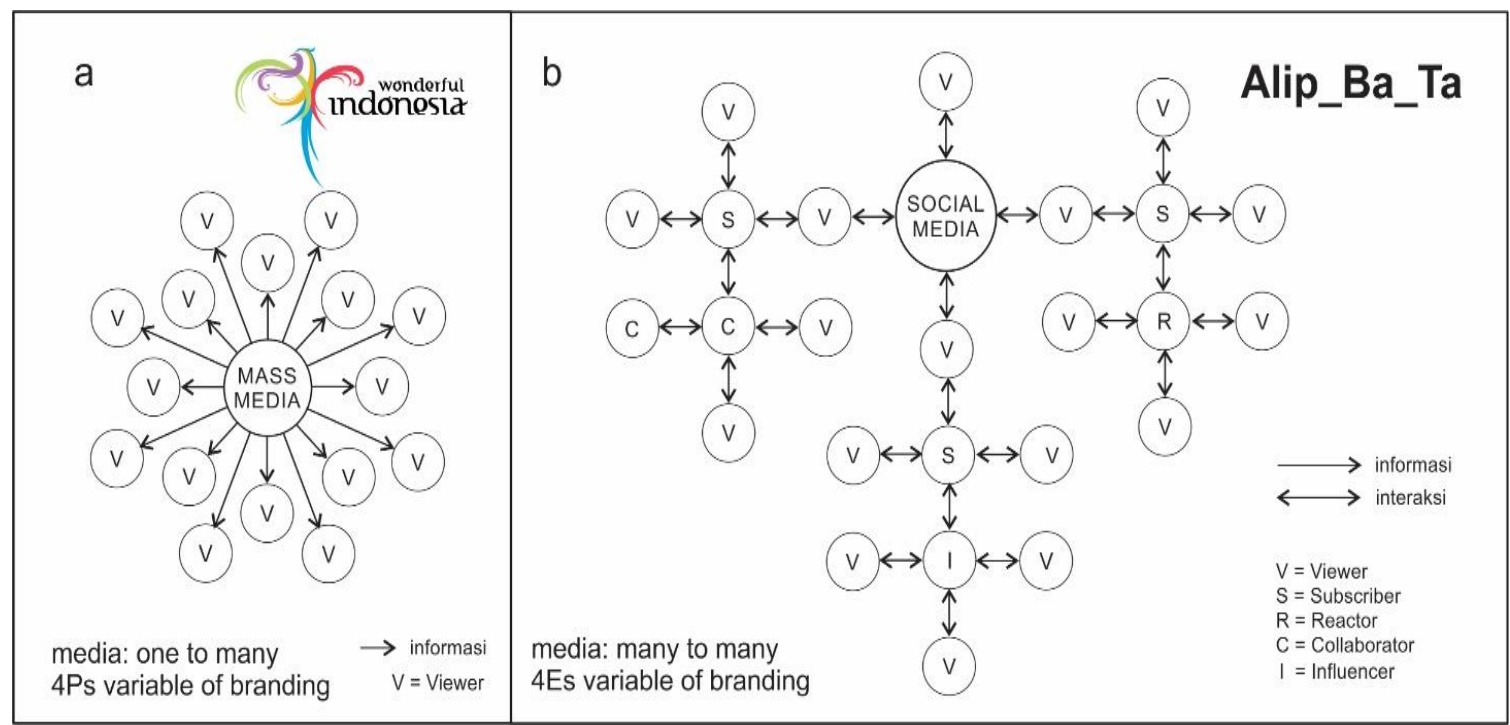

Figure 2. (a) Mass Media Communication Scheme; (b) Social Media Communication Scheme.

the cost of producing process and its rarity, or in other words, pricing is determined based on the concept of supply and demand. Today, pricing terms are increasingly blurred, as prices are seen more as a reward for what consumers pay. Consumers prefer solutions that offer the highest value rather than simply the lowest price. If Wonderful Indonesia Program costs a lot of money to achieve its goals, Alip_Ba_Ta offers an increase in value exchange that actually increases the engagement channel of the reactors, collaborators, and influencers. Alip_Ba_Ta not only offers what viewers get when they consume the uploaded content, but what they will "become" when reacting, collaborating, and influencing the content. From the various statements submitted, they thanked Alip_Ba_Ta and Alipers that after reacting or collaborating on Alip_Ba_Ta's content, they found that their viewers and subscribers who were Indonesian citizens had increased significantly. Having a relationship with Alip_Ba_Ta makes them boosted to become famous YouTubers. Alip_Ba_Ta is able to offer a certain standard price that is accepted by its viewers, in return Alip_Ba_Ta will get a higher chance to exist. Alip_Ba_Ta's existence physical medium to disseminate the image of a nation. The government's branding strategy in campaigning for the Wonderful Indonesia program is carried out by participating in tourism exhibition events in various countries, which are the target market. This strategy is in line with the method presented by Wally Ollin that tactics and ways of branding communication are often influenced by certain cultural patterns, especially popular culture which takes into account the characteristics of the target audience in which they live [33] .

In this digital age, having a storefront around the target audience is no longer enough. Now, the Place variable has evolved into Every place in digital branding. Everyplace variable synergizes the characteristics of the target audience that demands the breadth and convenience of access to branding objects as they wish. The evolution of the Place variable was responded by Alip_Ba_Ta through the nomadic concept of the subject, namely a digital native multitasking individual who moves in silence. Nomadic concept is the actual practice of flexible citizenship, a temporary, interim citizenship based on delinking ethnic origin from nationality and 
citizenship and then combining them in different ways [34]. Even though he is stay in the setting of the fingerstyle guitar playing room, his charm moves into a subject that is circulated around the world by spreading his Indonesian sense. That's how Alip_Ba_Ta captures, anticipates, and encourages the audience's mood through playing fingerstyle guitar on his YouTube channel.

Branding communication is used to generate and persuade brand awareness so that the perception in target audiens mind is in line with the brand image concept desired by the branding program. This communication generally refers to the Promotion variabel in modern branding concept. The Ministry of Tourism conducts a place branding promotion campaign (although it is referred as a nation branding effort in the 2018 Ministry of Tourism Strategy) to increase the number of foreign tourist visits to Indonesia [31]. This campaign strategy was carried out using the BAS (Branding - Advertising - Selling) approach, which mainly used the paid media and participated in tourism exhibitions. Television media and exhibitions are the main choice. Throughout 2018, Woderful Indonesia has been involved in various world-class tourism exhibition events that are oriented towards material physical culture. Information about the Indonesian nation brand is presented in the physical form of various tourist destinations in these exhibition spaces. In fact, the role of branding is now no longer to inform and and persuade but rather to provide a consistent and positive message in line with the values and experiences of a brand.

In digital branding concept, this term is called Evangelism, which is equated with Word of Mouth marketing. In practice, Evangelism uses customers as "good news agents This is very beneficial because a brand does not need to spend so much effort to get recognition. Alip_Ba_Ta just needs to be consistent with his competence, style, and quality, then let others spread the good news about his brand personality. Viewers, subscribers, reactors, ollaborators, and Alipers become Alip_Ba_Ta's evangelists in the practice of digital branding.

The scheme above clearly illustrates that each type of media has a pattern that reflects the performance of communication with its target audience. The mass media (figure $2 \mathrm{a}$ ) becomes the sole source of semiotics that works within the legal framework of momen opname. Call it television, for example, because of its communication performance, it was chosen to be the main medium to disseminate the message of the Wonderful Indonesia campaign to all over the world which was declared as nation branding. In fact, the symbolic narrative of Wonderful Indonesia has the potential to create distortions in the comprehensive understanding of nation branding. Wondeful Indonesia is actually just a place branding, a small part of nation branding. In the law of the momen opname, although television is capable of reaching a very large audience in a large (massive) area, it is only able to give an overview of the beauty of Indonesia.

Yet it is believed that the state is perceived by what they do, not by what they say. To prolong its exposure, television applies the second law, namely repetition. The higher the repetition, the cumulative awareness of nation branding will be higher. Television media, which is identified through its owner, its wide reach, very large target audience, and the law of repetition, reduces momentary of momen opname, and the reasons that facilitate the government control in disseminating the message of nation branding. The consequences of this convenience must be paid with a large media budget. Academics (as branding scientific authority holders), branding consultants (as professional practitioners of branding programs), television station owners (as institutions that facilitate branding campaign dissemination), and the government (as brand managers) are the main discourse tenors in the nation branding ecosystem circle to strengthen mass media communication patterns, one to many.

Being in the binary opposition of mass media, social media (figure $2 b$ ) provides an opportunity for all individuals to become sources of semiotics. The performance of social media takes place within the legal framework of gotong royong to show what they do, not just what they say. Call it YouTube, for example, because the performance of the mutual cooperation has made it chosen by many individuals who autonomously express a variety of competencies. Alip_Ba-Ta expresses his musical competence through his fingerstyle guitar playing, which attracts many people, and many of them accept it as a representation of Indonesia.

Although not as massive as the number of television viewers, YouTube facilitates interactions between individuals across national boundaries in the name of common interests. The performance of Alip_Ba_Ta's YouTube account can be audited through channel analytics that highlights the algorithm from overview factors (viewers, subscribers), reach (impressions, unique viewers), engagement (watch time in hour, average view duration), audience (returning viewers, new viewers). 
The widespread exposure of Alip_Ba_Ta's YouTube channel is framed by an unstoppable viral law. The more viral the channel, the awareness of the Indonesian nation brand, that is inherent in the figure of Alip_Ba_Ta, will increase accumulatively. The unstoppable viral law makes social media untouchable by discourse participants. Academics do not yet have a solid theoretical foundation for this kind of social media modelling in nation branding context.

Branding consultants tend to be disrupted by Alip_Ba_Ta's role in the nation's imaging practice. There is no fact that the government is called to care about the contribution of the digital native generation in increasing Indonesia's brand awareness. It is precisely the evangelists of Alip_Ba_Ta who are the interpreters of amplifying the image of the nation because they almost always associate the figure of Alip_Ba_Ta with Indonesia. The role of such evangelists is to ensure that the communication pattern of social media is - many to many.

\section{CLOSING}

From the discussion of this critical study, it is believed that there is a gap between the nation branding practice carried out by the government and by the digital native generation. From the discussion of this critical study, it is believed that there is a gap between the nation branding practice carried out by the government and by the digital native generation. The gap occurs because different ways of articulating the authenticity of nation branding.

The government implements nation branding practices framed by academic concepts, which include an understanding of the existence of branding theory (ontology), the process of acquiring branding knowledge (epistemology), and the usefulness value of branding knowledge (axiology). On the other hand, the digital native generation autonomously expresses their abilities, which unconsciously increases the nation's brand awareness. The contribution of the digital native generation in nation branding takes place non-ontologically, nonepistemologically, non-axiologically. Their way is to "act" on social media, while the government's way is to "talk" to the mass media. This is the basis for redefining nation branding. Branding is no longer a statement about nothing to do to the product (cq. Nation brand) but in the mind, but branding is what you do to the product not the mind. The digital native generation pioneered this redefinition.
In order to reduce the gap between theory and practice, it is necessary to have two-way communication that synergizes between the steps taken by the government in building nation branding and the activities carried out by the digital native generation. The government needs to actively empower and encourage digital natives as part of the conceptor and actor of nation branding in government programs. On the academic side, it is necessary to redefine branding, namely branding as "what you do to the product not the mind", because the image of a nation is judged by what the state does, not by what it says. This new definition needs to be put into practice so that the academic world can get out of the previous comfort zone that defines branding as nothing to do to the product but in the mind.

\section{REFERENCES}

[1] Xi Shen \& X. Tian, Academic Culture and Campus Culture of Universities. J Higher Education Studies. 2012. 2. DOI : 10.5539/hes.v2n2p61.

[2] A.E. Budiwaspada, and Fadillah, Locality Value As A Reflection Of Core Values In Corporate Culture: A Study Of Local Advertising Agency. Jurnal Sosioteknologi, ITB, 2018; 17 (2): 228235 ;

[3] H.A. Wani, Impact of Globalization on World Culture. Research J. Humanities and Social Sciences. April-June, 2011; 2(2): 33-39

[4] F. Satria and Fadillah, Konsep City Branding dan Identifikasi Nilai Lokal pada Kota-Kota Indonesia dalam Mendukung Nation Branding Indonesia. Jurnal Desain, 2021; 8 (2), 147-158

[5] IDN Researce Institute, Indonesia Millennial Report 2020, https://cdn.idntimes.com/contentdocuments/Indonesia-millennial-report-2020by-IDN-Research-Institute.pdf., 2020.

[6] Maria De Moya and R. Jain, Communicating Nation Brands through Mass and Social Media, Social Media and Networking, 2014; 409-425. DOI : 10.4018/978-1-4666-5003-9.ch022.

[7] Z. Xiang \& U. Gretzel, Role of social media in online travel information search, Tourism Management, 2010;31 (2), pp. 179-188.

[8] M. Waters, Globalization, London: Routledge; 1995. 
[9] M. A. K. Halliday, Language as Social Semiotic: the Social Interpretation of Language and Meaning, Edward Arnold, 1994.

[10] Doyle, P. Branding, in The Marketing Book, Second Edition (M.J. Baker,ed.). UK: Butterworth-Heinemann; 1992.

[11] S. Misoch, Card Stories on YouTube: A New Frame for Online Self-Disclosure, Media and Communication, 2014; 2(1), 2-12.

[12] www.staista.com. Most popular social networks worldwide as of April 2021, ranked by number of active users. https://www.statista.com/statistics/272014/globa 1-social-networks-ranked-by-number-of-users/. Acessed July 13th 2021, 11:56 AM.

[13] S. Pereira, P. Moura and J. Fillol, The YouTubers Phenomenon: What makes YouTube stars so popular for young people?, Journal of Communication. 2018; pp. 107 - 123. DOI : 107. 10.14201/fjc201817107123.

[14] J. Burgess, From 'Broadcast yourself' to 'Follow your interests': Making over social media, International Journal of Cultural Studies, 2015; 18(3), pp. 281-285. DOI: https://doi.org/10.1177/1367877913513684

[15] Van Dijck J, 'You have one identity': performing the self on Facebook and LinkedIn, Media, Culture \& Society,. 2013; 35(2): 199215. DOI: $10.1177 / 0163443712468605$

[16] S. Shaviro, Connected, or What It Means to Live in the Network Society, Minneapolis: University of Minnesota Press, 2003.

[17] A. Martelloni, A. P. McPherson and M. Barthet, Percussive Fingerstyle Guitar through the Lens of NIME: an Interview Study, 2020.

[18] D. McNally, D. and K. D. Speak. Be Your Own Brand: A Breakthrough Formula for Standing Out from the Crowd. 2002.

[19] S. McQuali, Mass communication theory: An introduction, London: Sage Publications, 1983.

[20] Prensky, M. "Digital Natives, Digital Immigrants Part 1" On the Horizon Vol. 9 No. 5, October 2001; pp.1-6

[21] Prensky, M. Digital Natives, Digital Immigrants Part 2: Do they really think differently?. On the Horizon. Vol. 9 No. 6, 2001; pp.1-6.
[22] Tapscott, D. Grown Up Digital: How the Net Generation Is Changing Your World. New York: McGraw-Hill, 2009.

[23] E. J. Helspe \& R. Eynon. Digital natives: where is the evidence? British Educational Research Journal. Vol. 36, No 3 June 2010 pp. 503 - 520. 2010

[24] Himma-Kadakas, M. The food chain of YouTubers: engaging audiences with formats and genres. Observatorio (OBS*). 2018. DOI : 10.15847/obsOBS0001385.

[25] Fägersten, K. B. The role of swearing in creating an online persona: The case of YouTuber PewDiePie. Discourse, Context \& Media. 2017; 18, 1-10.

[26] Bienstock, R. This Indonesian YouTuber's acoustic fingerstyle cover of Guns N' Roses' Sweet Child O' Mine is Driving Guitarists Wild. Guitar World (serial online). 2020. https://www.guitarworld.com/news/thisindonesian-youtubers-acoustic-fingerstylecover-of-guns-n-roses-sweet-child-o-mine-isdriving-guitarists-wild

[27] Anholt S. Beyond the Nation Brand: The Role of Image and Identity in International Relations. The Journal of Public Diplomacy [serial online]. 2013;2 (1):17https://surface.syr.edu/exchange/vol2/iss1/1/

[28] Dinnie, K. Nation branding: Concepts, issues, practice. Nation Branding: Concepts, Issues, Practice. 2010; 1-264. DOI : $10.4324 / 9780080554570$.

[29] Fan, Y. Branding the nation: towards a better understanding", Place Branding and PublicDiplomacy. 2018 ;Vol. 6 No. 2, pp. 97103

[30] Nye, J. S. Soft power: The means to success in world politics. New York, NY: Public Affairs. 2004.

[31]

htps://www.kemenparekraf.go.id/asset_adm in/assets/uploads/media/pdf/ media_1569914736_LAKIP_KEMENPAR_TA _2018_update_12_september_19_master.pdf [cited 2021 Jul 12].

[32] Dominici, G. From Marketing Mix to eMarketing Mix: a literature overview and classification. International Journal of Business 
and Management. 4. 2018; DOI : $10.5539 / \mathrm{ijbm} . v 4 \mathrm{n} 9 \mathrm{p} 17$.

[33] Olins, W. Wally Olins on Brand. London: Thames \& Hudson, 2004.

[34] Braidotti, Rosi. Writing as a Nomadic Subject. Comparative Critical Studies. 2014. DOI: 11. 163-184. 10.3366/ccs.2014.0122. 